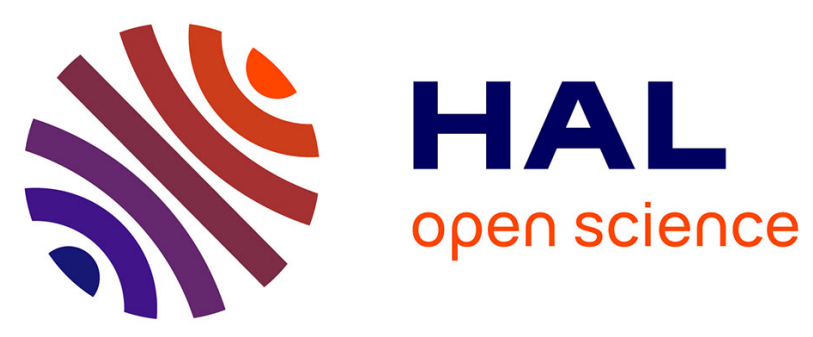

\title{
Food-dependent set-up of the DiDGI@ dynamic in vitro system: Correlation with the porcine model for protein digestion of soya-based food
}

Yohan Reynaud, Angélique Couvent, Aline Manach, David Forest, Michel Lopez, Daniel Picque, Isabelle Souchon, Didier Remond, Didier Dupont

\section{To cite this version:}

Yohan Reynaud, Angélique Couvent, Aline Manach, David Forest, Michel Lopez, et al.. Fooddependent set-up of the DiDGI® dynamic in vitro system: Correlation with the porcine model for protein digestion of soya-based food. Food Chemistry, 2021, 341, pp.128276. 10.1016/j.foodchem.2020.128276 . hal-02983872

\section{HAL Id: hal-02983872 \\ https://hal.inrae.fr/hal-02983872}

Submitted on 30 Oct 2020

HAL is a multi-disciplinary open access archive for the deposit and dissemination of scientific research documents, whether they are published or not. The documents may come from teaching and research institutions in France or abroad, or from public or private research centers.
L'archive ouverte pluridisciplinaire HAL, est destinée au dépôt et à la diffusion de documents scientifiques de niveau recherche, publiés ou non, émanant des établissements d'enseignement et de recherche français ou étrangers, des laboratoires publics ou privés.

\section{(ㅇ)(1) $\$$}

Distributed under a Creative Commons Attribution - NonCommercial - NoDerivatives 44.0 


\title{
Food-dependent set-up of the DiDGI ${ }^{\circledR}$ dynamic in vitro system: Correlation with the porcine model for protein digestion of soya-based food
}

\author{
Yohan Reynaud ${ }^{\mathrm{a}, \mathrm{b}, *}$, Angélique Couvent ${ }^{\mathrm{a}}$, Aline Manach ${ }^{\mathrm{d}}$, David Forest ${ }^{\mathrm{d}}$, Michel Lopez ${ }^{\mathrm{a}}$, \\ Daniel Picque $^{\mathrm{d}}$, Isabelle Souchon ${ }^{\mathrm{d}}$, Didier Rémond ${ }^{\mathrm{c}}$, Didier Dupont ${ }^{\mathrm{b}}$ \\ a IMPROVE SAS, F-80480 Dury, France \\ ${ }^{\mathrm{b}}$ STLO, INRAE, INSTITUT AGRO, F-35042 Rennes, France \\ ${ }^{\mathrm{c}}$ Université Clermont Auvergne, INRAE, UNH, Unité de Nutrition Humaine, F-63000 Clermont-Ferrand, France \\ ${ }^{\mathrm{d}}$ Université Paris-Saclay, INRAE, AgroParisTech, SayFood, F-78850 Thiverval-Grignon, France
}

\section{A R T I C L E I N F O}

\section{Keywords:}

Tofu

Soya milk

Mini-pig

Gastric emptying

Intestinal transit

\begin{abstract}
A B S T R A C T
The present study compared in vivo protein digestion in a miniature pig model with the dynamic in vitro system DiDGI $^{\circledast}$, using three digestive compartments (stomach, duodenum, and jejunum + ileum). Two soya-based meals-commercial soya milk and tofu-were studied, each with the same macronutrient content but different macrostructures. Our aim was to first deduce from the in vivo experiments in pigs key digestive parameters such as gastric $\mathrm{pH}$, stomach emptying kinetics, and intestinal transit time, in order to design a relevant set-up for the dynamic in vitro system. Then, we compared digestive samples collected at fixed sampling times from both in vivo and in vitro models regarding different values related to proteolysis. We observed similar evolutions of gastric peptide distribution and duodenal proteolysis between models. Overall, apparent ileal digestibility of nitrogen was similar in vitro and in vivo and the differences between the two meals were conserved between models.
\end{abstract}

\section{Introduction}

Animal experiments are increasingly difficult to perform due to the economic resources they require and the ethical concerns that must be addressed. Despite this, it is still standard—indeed, recommended—for assessments of protein and amino acid digestibility to be conducted using human or pig models (FAO, 2013). In vitro systems could present suitable alternatives, but they first must be shown to mimic as much as possible real physiological conditions and must be validated using in vivo data. For example, Rozan et al. (1997) examined quantitative correlations between digestion end-points obtained in vivo and in vitro, specifically by comparing true digestibility assessed in rats with the final degree of hydrolysis measured using the pH-stat method. Other studies have gone further by comparing different in vitro protocols and methods; for example, the true digestibility of chickpea quantified in rats was found to correlate better $\left(\mathrm{R}^{2}=0.6785, \mathrm{p}=0.0640\right)$ with the degree of hydrolysis determined using O-phthalaldehyde after incubation with pepsin/pancreatin (Tavano, Neves and da Silva Júnior, 2016). Similarly, evaluations of in vitro static nitrogen or amino acid digestibility-in which samples were either filtered with a $1.2-\mu \mathrm{m}$ filter
(Millipore) (Saunders, Connor and Booth, 1973) or a 1 kDa-cut off dialysis bag (Vachon et al., 1987; Rozan et al., 1997)—have found favourable correlations with different nutritional quality indicators of proteins measured in rats. Instead, correlations between the apparent ileal digestibility of amino acids obtained from pigs and in vitro static amino acid digestibility (after filtration of the samples on a glass filter, pore size 40-90 pm; Cho \& Kim, 2011) were mixed, with the coefficient of correlation variable from one amino acid to another. Proteolysis has also been examined in vitro using enzyme-linked immunosorbent assays (ELISA; Ménard et al., 2014) or by LC-MS/MS identification of released peptides (Egger et al., 2015). In these studies, though, comparisons with in vivo results were globally affected by a high degree of inter-individual variability, which forced the authors to differentiate each animal in the presentation of the results. This complicated the analysis, because it was difficult to determine if a strong correlation was due to the quality of the simulation or an artefact of the high in vivo variability (Walther et al., 2019). In general, the number of possible set-ups to replicate digestion in vitro is large, and a major remaining challenge is to identify those that are most physiologically relevant (Bohn et al., 2018). To address this, the INFOGEST network recently published standardised

\footnotetext{
* Corresponding author at: Yohan Reynaud, IMPROVE SAS, F-80480 Dury, France.

E-mail addresses: yohan.reynaud@improve-innov.com (Y. Reynaud), angelique.couvent@improve-innov.com (A. Couvent),

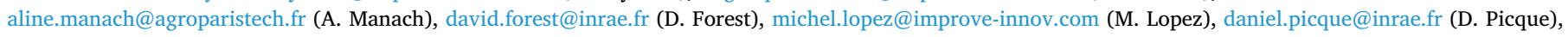
isabelle.souchon@inrae.fr (I. Souchon), didier.remond@inrae.fr (D. Rémond), didier.dupont@inrae.fr (D. Dupont).
} 
approaches for static protocols, i.e. those that do not take into consideration the kinetics of digestion (Brodkorb et al., 2019). However, no such consensus has yet emerged for dynamic systems of digestion. Indeed, these models are even more complex than their static counterparts, and require extensive knowledge of how digestive physiology changes over time (e.g., gastric emptying kinetics or $\mathrm{pH}$ changes). To address this challenge, different teams have designed multiple systems that aim to replicate these dynamic conditions in vitro. Of these, the Vatier (Nunez, Bichot and Paris, 1998) and the Mainville (Mainville, Arcand and Farnworth, 2005) models consist of a succession of reactors, each connected to the next, which mimic the stomach and other compartments of the small intestine. More recently, the DiDGI ${ }^{\circledast}$ (Digesteur Dynamique Gastro-Intestinale; Ménard et al., 2014 or the ESIN (Engineered Stomach and small Intestine; Guerra et al., 2016) systems were developed on the same basis. The most well-known system is the TIM-1 (Minekus, 2015), which also simulates contractile aspects of digestion. However, only limited data exist that assess the correlation of these in vitro systems with in vivo models, and most of these data focus on the digestion of milk proteins. To our knowledge, correlations between in vivo and in vitro digestion of plant protein have only been performed using static in vitro models and in vivo data from the rat model. However, the rat model has several drawbacks with respect to mimicking human digestion, as the eating behaviour of rats and their physiological parameters of digestion are not directly comparable to those of humans (Davies and Morris, 1993). Instead, the gastrointestinal conditions in pigs are much more similar to those of humans, both anatomically and physiologically (Henze et al., 2018) and for this reason, the porcine model should be preferred for studies of protein digestion and digestibility (FAO, 2013).

The aim of this study was to examine the correlation between a porcine model of food-protein digestion and a dynamic in vitro gastrointestinal system, the DiDGI ${ }^{\oplus}$. Specifically, we used data from three sets of experiments on cannulated mini-pigs (gastric, duodenal, and ileal) to (i) determine optimal parameters for the set-up of the in vitro system $(\mathrm{pH}$, chyme transfer) and (ii) compare the evolution of digestion in both in vivo and in vitro models, specifically with respect to dry matter content, local apparent degree of proteolysis, and molecular weight distributions of peptides. This latter goal was accomplished by comparing the digestion of two soya-based foods (soya milk and tofu) in the DiDGI $^{\circledR}$ and in mini-pigs. Ileal digestibilities were also obtained from both models and compared.

\section{Materials and methods}

\subsection{Test meals}

Two soya-based food matrices were tested: commercial tofu and commercial soya milk. Soya milk was UHT- (Ultra-High Temperature) packed. Compositions of foodstuffs have been previously published (Reynaud, Lopez, Riaublanc, Souchon, \& Dupont, 2020; Binnerts, Van't Klooster, \& Frens, 1968). Food matrices were supplemented with maltodextrin, sugar, and soya oil (Emile Noël, France) in order to standardise the amounts of protein $(30.0 \mathrm{~g})$, fat $(23.1 \mathrm{~g})$, and calories (980 kcal) in each diet (Table S1). The meals used for the DiDGI ${ }^{\circledR}$ experiments had the same nutrient proportions ( $7.5 \mathrm{~g}$ of protein, $5.8 \mathrm{~g}$ of fat and carbohydrates for a total of $245 \mathrm{kcal}$ ).

Dry matter content (DM) was determined by oven-drying at $105{ }^{\circ} \mathrm{C}$ overnight. Crude fat content was determined using the Randall method after $12 \mathrm{~h}$ incubation in $1 \mathrm{M} \mathrm{HCl}$ (ISO, 2008). Total nitrogen content was measured using the Kjeldahl method according to Thiex, Manson, Anderson, and Persson (2002). To calculate crude protein content, conversion factors of 5.36 for pea proteins, 5.50 for soya, and 5.50 for wheat proteins were used according to (Mariotti, Tomé and Mirand, 2008). Starch content was measured using a polarimeter (European Commission, 2009). Gross energy was calculated from macronutrient content using standard conversion factors.

\subsection{In vivo digestion study on mini-pigs}

All procedures were conducted in accordance with European guidelines (Directive 2010/63/EU) and were approved by the Auvergne Animal Experimentation Ethics Committee (CEMEAA) and the French Government. Yucatan mini-pigs were housed in subject pens in a ventilated room with controlled temperature $\left(21{ }^{\circ} \mathrm{C}\right)$. Between sampling days, they received $500 \mathrm{~g} / \mathrm{d}$ of a standard diet for minipigs, distributed in two equal portions at 8:00 and 16:00, and had free access to water. They were divided into three groups.

\subsubsection{Gastric group}

The gastric test included four mini-pigs (weight $=24.9 \pm 1.2 \mathrm{~kg}$, 8 months old). Three weeks before the trials began, mini-pigs were surgically fitted with a cannula (silicone rubber; $12-\mathrm{mm}$ internal diameter, $17-\mathrm{mm}$ outer diameter) at the greater curvature in the lateroventral region of the corpus. Digesta were sampled a minimum of $5 \mathrm{~min}$ before ingestion, then $20,40,60,90,120,180,270,360$, and $450 \mathrm{~min}$ after ingestion of the meal. To each sample, $10 \mu \mathrm{l}$ of pepstatin A solution (P5318, \#027M4005V, Sigma-Aldrich, USA) were added per $\mathrm{ml}$ of digesta, at a concentration of $0.5 \mathrm{mg} \cdot \mathrm{ml}^{-1}$ in methanol/acetic acid (9:1). Samples were then placed in liquid nitrogen and stored at $-20{ }^{\circ} \mathrm{C}$.

\subsubsection{Duodenal group}

The duodenal test involved six mini-pigs (weight $=24.7 \pm 0.4 \mathrm{~kg}$, 8 months old). Three weeks before the experiment, a cannula (silicone rubber; $12-\mathrm{mm}$ internal diameter, $17-\mathrm{mm}$ outer diameter) was fitted on mini-pigs 5-10 cm under the pyloric sphincter, as described previously by Bauchart et al. (2007). Each meal contained a Cr-EDTA solution (30 ml, $2.77 \mathrm{mg}_{\mathrm{Cr}} \cdot \mathrm{ml}^{-1}$ ) as a liquid marker (Binnerts et al., 1968), and $450 \mathrm{mg}$ Ytterbium-acetate as a solid-phase marker (Siddons et al., 1985).

Duodenal sampling was performed a minimum of 5 min before ingestion and then $20,40,60,90,120,180,270,360$, and $450 \mathrm{~min}$ after ingestion of the meal. The $\mathrm{pH}$ of the collected duodenal content $(15 \mathrm{ml}$ maximum) was measured with an IFSET probe (1001-004 ISFET, Sentron, Holland), then the sample was divided into two parts. One part was freeze-dried (Pilot Freeze Dryer, Cryotec, France) for marker quantification; the other part was blocked with $1 \mathrm{mM}$ final concentration of Pefabloc SC (AEBSF) (24305500, Roche, USA) diluted in distilled water. Then, the blocked mixture was vortexed for $5 \mathrm{~s}$, placed in liquid nitrogen and stored at $-20{ }^{\circ} \mathrm{C}$ until analysis.

The freeze-dried portions of the collected duodenal contents were also used to determine the dry matter content (DM) of duodenal samples (based on the weight difference before and after freeze-drying).

Freeze-dried duodenal contents were then ground and prepared for microwave plasma-atomic emission spectrometry (MP-AES) with successive steps of mineralisation $\left(550{ }^{\circ} \mathrm{C}, 6 \mathrm{~h}\right)$, nitric acid dissolution ( 3 min boiling in $5 \% \mathrm{HNO}_{3}{ }^{-}(\mathrm{w} / \mathrm{w})$ ), and filtration (Whatman filter 4-7 $\mu \mathrm{m})$. The amount of chromium-labelled indigestible content was then determined with a 4210 MP-AES apparatus (Agilent). The percentage of markers recovered was calculated by multiplying the measured content of the marker by the fixed volume sampled from the cannula $(12 \mathrm{ml})$ and dividing this by the initial amount of the marker that was present in the meal.

\subsubsection{Ileal group}

The ileal test involved six mini-pigs (weight $=20.2 \pm 1.5 \mathrm{~kg}$, 8 months old). Three weeks before the experiment, mini-pigs were surgically fitted with a cannula (silicone rubber; 12-mm internal diameter, 17-mm outer diameter) at their distal ileum $(10 \mathrm{~cm}$ before the ileocecal valve). Chromium oxide $\left(\mathrm{Cr}_{2} \mathrm{O}_{3}\right)$ was used as an indigestible transit marker, and was added up to the amount of $0.3 \%$ of meal dry matter content.

Contents were collected between 1 and $9 \mathrm{~h}$ after the distribution of 
meals in pre-weighed plastic bags (Sachet Whirl-Pak, $120 \mathrm{ml}$, $7.5 \times 18.5 \mathrm{~cm}$ ) attached to the ileal cannula. Full bags were replaced with new ones as necessary. Content was immediately transferred to aluminium dishes (previously weighed) and stored at $-18^{\circ} \mathrm{C}$. Samples were pooled in 1 -h pools and stored at $-20{ }^{\circ} \mathrm{C}$.

Ileal samples underwent the same treatments as the freeze-dried duodenal samples, i.e. freeze-drying, grinding, and mineralisation, to enable chromium quantification in samples using microwave plasmaatomic emission spectrometry (4210 MP-AES, Agilent). Then, a representative sample of the entire postprandial period (per animal-meal combination) was constituted using a fixed percentage (DM basis) from each batch of collected effluent (hourly), starting from the first detection of chromium.

\subsection{Determination of operating parameters for the DiDGI ${ }^{\circledast}$ dynamic in vitro system}

\subsubsection{Gastric emptying equation}

Gastric emptying was modelled according to Elashoff's equation (Elashoff, Reedy and Meyer, 1982) and parameters were determined for each meal from mineral data collected through the duodenal cannula.

For each timepoint, the total amount of marker collected up to this time was summed. This function is thought to follow the equation:

$f(t)=A\left(1-2^{-\left(\frac{t}{t_{1 / 2}}\right)^{\beta}}\right.$

where $A$ is the maximum percentage of marker collected compared to initial marker intake; $\beta$ is the shape of the curve; and $t_{1 / 2}$ is the time at which $50 \%$ of the meal has been emptied from the compartment (here the stomach). The parameters of interest are $t_{1 / 2}$ and $\beta$, from Elashoff's equation. Our model assumed that the flux of chyme was continuous and homogeneous. To avoid aberrant regression, samples that did not demonstrate a plateau in their kinetics were removed from the analysis; after this filtering step, at least five animals per meal and per marker were retained for analysis. Regression parameters are presented in Fig. 1A.

\subsubsection{Intestinal transit flow}

Transit of the bolus from the mouth to the ileal cannula was estimated with formula (1). In initial tests, the plateau of recovered chromium was not reached (Fig. 1B), so we set $A$ (the maximum percentage of marker collected compared to initial marker intake) to 0.5 . This can be interpreted as the hypothesis that the maximum content that could be recovered through the ileal cannula was $50 \%$.

\subsection{3. $\mathrm{pH}$ in the stomach and duodenum}

We used food-dependent gastric acidification equations from a previous study (Reynaud, Buffière, et al., 2020), using the mean data of $\mathrm{pH}$ catheter probes. Duodenal kinetics of $\mathrm{pH}$ were deduced from a nonlinear regression of the $\mathrm{pH}$ measured in duodenal samples (Fig. S1).

\subsubsection{Endogenous secretions}

We simulated the saliva and basal gastric fluid present in the stomach when the chyme arrived by adding $12 \mathrm{ml}$ of simulated saliva fluid (SSF) and $40 \mathrm{ml}$ of simulated gastric fluid (SGF) to the initial meal. These solutions were prepared according to (Minekus et al., 2014) and quantities were determined based on euthanasia data (data not shown).

These amounts of endogenous secretions came from the recommendations of INFOGEST (Minekus et al., 2014). Therefore, in order to maintain the same global ratio of protein:protease from one meal to another, enzymes were injected as follows:

In the stomach, the total amount of pepsin units (P6887, \#SLBV3035, Sigma-Aldrich, USA) was 80000 per gram of food protein and the speed of injection was $0.5 \mathrm{ml} . \mathrm{min}^{-1}$ (concentration of the stock solution: $3333 \mathrm{U}_{\text {pepsin. }} \cdot \mathrm{ml}^{-1}$ ). In the duodenum, the total amount of trypsin units from pancreatin (P7545, \#SLBV6830, Sigma-Aldrich, USA) was 4000 per gram of food protein and the speed of injection was $0.25 \mathrm{ml} \cdot \mathrm{min}^{-1}$ (concentration of the stock solution: $333 \mathrm{U}_{\text {trypsin. }} \cdot \mathrm{ml}^{-1}$ ). Biliary acids solution (B8631, Sigma-Aldrich, USA) was secreted at $0.5 \mathrm{ml} . \mathrm{min}^{-1}$. For the first $30 \mathrm{~min}$, a $40 \mathrm{mmol}^{-1}$ solution of biliary acids was used, then the concentration was reduced to $20 \mathrm{mmol} \cdot \mathrm{l}^{-1}$.

\subsection{In vitro digestion study using DiDGI ${ }^{\circledast}$}

2.4.1. The dynamic three-compartment model of the gastrointestinal tract This study used a three-compartment system instead of the original two-compartment system described in (Ménard et al., 2014). In the original system, the two compartments represent the stomach and the small intestine, respectively; to this set-up, Adouard and colleagues (2016) added a third compartment to split the small intestine into 2 independent sections i.e. the duodenum and the jejunum + ileum (Adouard et al., 2016). In our experiment, the third compartment emptied into a receptacle, the contents of which were analogous to those collected though the ileal cannula of mini-pigs.
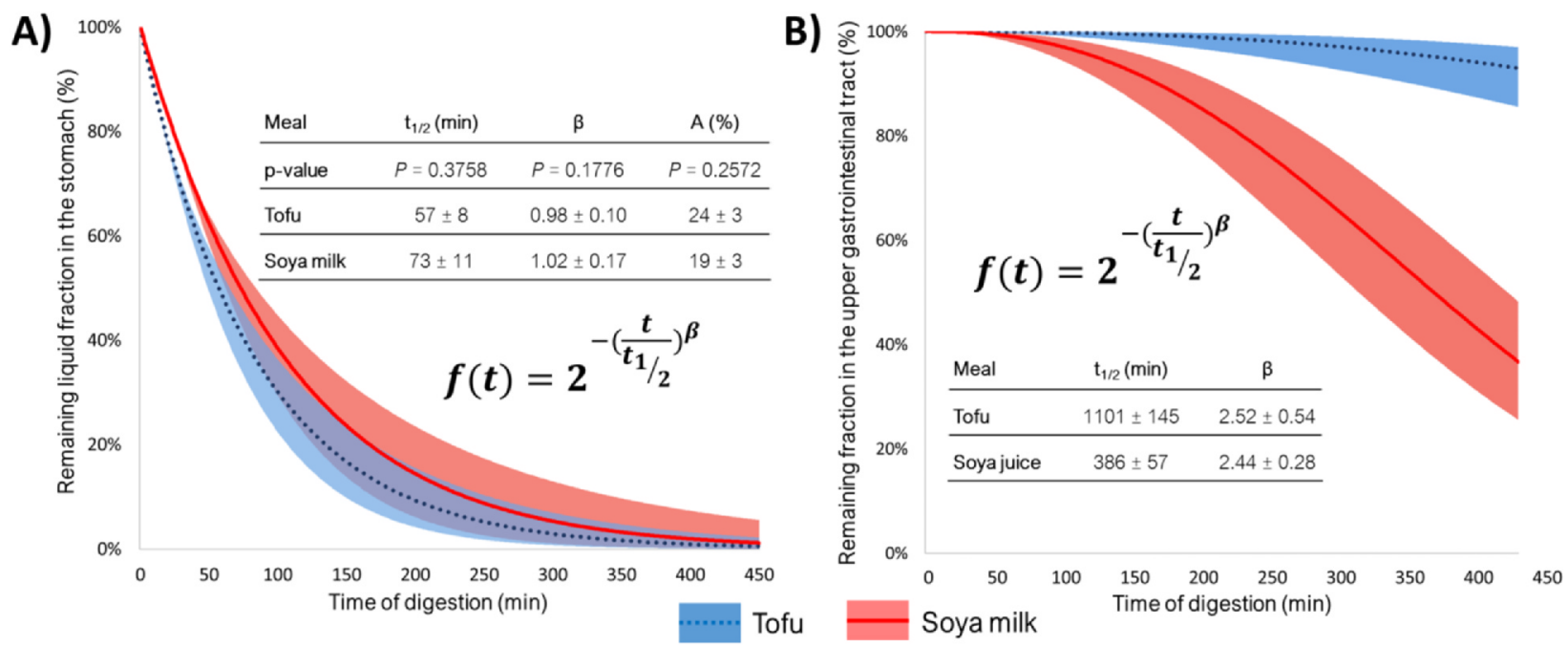

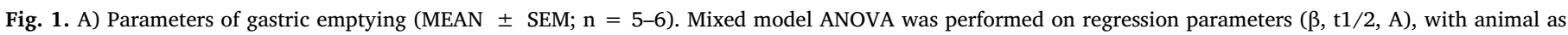

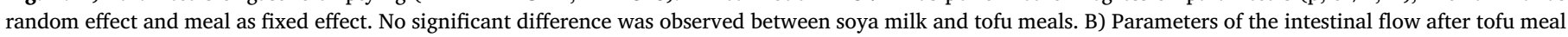

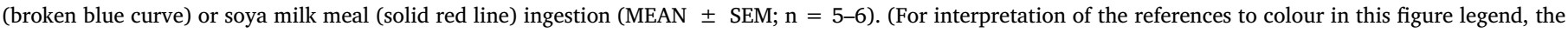
reader is referred to the web version of this article.) 
Table 1

Parameters of the DiDGI ${ }^{\circledR}$ digestion.

\begin{tabular}{|c|c|c|c|}
\hline Parameters & Soya milk & Tofu & \\
\hline Time of digestion & $360 \mathrm{~min}$ & & \\
\hline Temperature & $37^{\circ} \mathrm{C}$ & & \\
\hline Gastric $\mathrm{pH}$ equation & $1.8+\frac{5.5}{1+\exp (0.40(2-t))}+\exp (0.04(t-174))$ & $1.5+\frac{4.7}{1+\exp (0.40(3-t))+\exp (0.02(t-9))}$ & $+\frac{1.5 \times \ln (1+\exp (-t / 300))}{\ln (2)}$ \\
\hline Duodenal pH equation & $2.86+\frac{3.41}{(1+191.26)^{0.89}}$ & & \\
\hline Gastric emptying equation & $2^{\left(\frac{-t}{73}\right)^{1.02}}$ & $2^{\left(\frac{-t}{57}\right)^{0.98}}$ & \\
\hline Fixed volume of the duodenum & $50 \mathrm{ml}$ & & \\
\hline Intestinal flow equation & $2^{\left(\frac{-t}{386}\right)^{2.44}}$ & $2\left(\frac{-t}{1101}\right)^{2.52}$ & \\
\hline Pepsin secretion & \multirow{3}{*}{\multicolumn{3}{|c|}{$\begin{array}{l}600000 \mathrm{U}_{\text {pepsin }} \text { over } 360 \mathrm{~min}\left(0.5 \mathrm{ml} \cdot \mathrm{min}^{-1}\right)(\mathrm{P} 6887) \\
30000 \mathrm{U}_{\text {trypsin }} \text { over } 360 \mathrm{~min}\left(0.25 \mathrm{ml} \cdot \mathrm{min}^{-1}\right)(\mathrm{P} 7545) \\
40 \mathrm{mmol} . \mathrm{l}^{-1} \text { until } 30 \mathrm{~min} \text {, then } 20 \mathrm{mmol} . \mathrm{l}^{-1}\left(0.5 \mathrm{ml} \cdot \mathrm{min}^{-1}\right)(\mathrm{B} 8631)\end{array}$}} \\
\hline Pancreatin secretion & & & \\
\hline Bile secretion & & & \\
\hline
\end{tabular}

\subsubsection{Digestion programme}

The digestion programme was designed following consultation with available in vivo data and existing literature. It was food-dependent and is summarised in Table $1 . \mathrm{pH}$ was regulated with $0.2 \mathrm{~N} \mathrm{HCl}$ and $1 \mathrm{~N}$ $\mathrm{NaOH}$ solutions.

2.4.3. Post-hoc treatment of ileal content for the simulation of intestinal absorption

All contents collected from the third DiDGI ${ }^{\circledR}$ compartment corresponded to the in vivo effluent arriving at the ileal cannula; in both cases, ileal contents were collected in aluminium plates on the same sampling schedule. At least once per hour of digestion, once the chyme reached the in vitro "ileum", contents were manually stirred and a 2-ml sample was collected and blocked with $1 \mathrm{mM}$ final concentration of Pefabloc SC (76307, \#117M4033V, Sigma-Aldrich, USA) diluted in distilled water. Samples were vortexed for $5 \mathrm{~s}$ and put on ice before being stored at $-20^{\circ} \mathrm{C}$. The remainder of the ileal contents was frozen at $-20{ }^{\circ} \mathrm{C}$ before being freeze-dried.

All of the frozen samples from a given digestion were pooled, homogenised, and centrifuged ( $5000 \mathrm{G}, 10 \mathrm{~min}, 20{ }^{\circ} \mathrm{C}$ ). Pellets and supernatants were weighed, and total nitrogen content was determined (Kjeldahl method). Supernatants were then subjected to different methods for simulating intestinal absorption, described below. From those processes, we generated values for simulated-absorbed and simulated-non-absorbed fractions of ileal content.

\subsection{Values to be correlated between in vivo and in vitro experiments}

\subsubsection{Dry matter content (DM) in duodenal and ileal sections}

Dry matter content was determined from the difference between sample weights before and after freeze-drying, with the exception of the duodenal contents sampled from the DiDGI ${ }^{\circledR}$, for which the oven method $\left(105{ }^{\circ} \mathrm{C}\right.$, overnight) was used.

\subsubsection{Proteolysis in gastric and duodenal sections}

Determination of the concentration of $\alpha$-amino groups, an indicator of proteolysis in the stomach and the duodenum, was carried out using the ninhydrin reaction described by (Moore and Stein, 1954). This technique was applied to gastric and duodenal samples that had been blocked immediately after they had been taken. The total nitrogen content of each sample was measured (Kjeldahl method) to calculate the "local apparent degree of proteolysis" (LADP) with the following equation, where the density of contents was considered to be 1 :

$\operatorname{LADP}(\%)=\frac{A G \text { in supernatant }\left(\mathrm{mg}(\mathrm{N}) \cdot \mathrm{l}^{-1}\right)}{\text { Ntot in sample }\left(\mathrm{gN} \cdot 100 \mathrm{~g}^{-1}\right)} \times 10^{-2}$

\subsubsection{Molecular weight determination by size-exclusion HPLC (HPSEC) of} gastric samples

Gastric samples taken from mini-pigs and from the DiDGI ${ }^{\circledR}$ prior to ingestion and at $20,60,90$, and 180 min post-ingestion were analysed with respect to the molecular weight distribution of peptides. Samples were centrifuged $\left(5000 \mathrm{G}, 10 \mathrm{~min}, 20{ }^{\circ} \mathrm{C}\right.$ ), diluted $1: 10$ in an trifluoroacetic acid (TFA):acetonitrile:water buffer (0.01:2:10 v:v:v), and then filtered through a $0.40-\mu \mathrm{m}$ pore-size filter. Peptides were separated according to their molecular weight with a column (Shodex Asahipak GF-310HQ, Interchyme, France) that was connected to a Waters e2695 separation module equipped with a Waters $2998 \mathrm{UV} /$ Visible detector with diode array (Waters Inc., USA). Elution was performed under an isocratic $0.2 \mathrm{ml} . \mathrm{min}^{-1}$ flow of TFA:acetonitrile:water buffer at $37{ }^{\circ} \mathrm{C}$. Detection was performed at $214 \mathrm{~nm}$. Sample injection volume was $30 \mu \mathrm{l}$. The column was calibrated by injecting $30 \mu \mathrm{l}$ of five markers of known molecular weight, each at a concentration of $2 \mathrm{mg} \cdot \mathrm{ml}^{-1}$ : blue dextran $(2000 \mathrm{kDa})$ and carbonic anhydrase $(30 \mathrm{kDa})$, cytochrome $C$ $(12.384 \mathrm{kDa})$, vitamin B12 (1.855 kDa), and tripeptide GlyGlyGly (189 Da). The resulting calibration curve (log molecular weight vs retention time) enabled us to distinguish among 13 ranges of molecular weight: > $35 \mathrm{kDa}, 35-18 \mathrm{kDa}, 18-10 \mathrm{kDa}, 10-6 \mathrm{kDa}, 6-3 \mathrm{kDa}$, 3-2.5 kDa, 2.5-2 kDa, 2-1.5 kDa, 1.5-1 kDa, 1-0.8 kDa, 800-500 Da, 500-204 Da, < 204 Da.

\subsubsection{Protein digestibility}

Using the data obtained from the mini-pigs fitted with ileal cannulas, the apparent and true ileal digestibility of crude protein and amino acids were determined (Reynaud et al., 2021). These reported values were used here to study the correlation between in vivo- and DiDGI ${ }^{\circledast}$-generated data.

Total nitrogen content (elemental analyser, vario ISOTOPE cube, Elementar) of both the simulated-absorbed and simulated-non-absorbed fractions of the DiDGI ${ }^{\circledR}$ ileal content were determined.

Estimates of digestibility obtained from the DiDGI ${ }^{\circledR}$ system are hence expressed as the ratio $\mathrm{X}_{\text {simulated absorbed fraction }} /\left(\mathrm{X}_{\text {simulated absorbed }}\right.$ fraction $+X_{\text {simulated non-absorbed fraction }}$ )

\subsubsection{Data \& statistical analysis}

Data are disclosed as mean \pm SD (standard deviation) for in vitro data and as mean \pm SEM (standard error of the mean $=\mathrm{SD} / \sqrt{ }$ number of replicates) for in vivo data or To present the data, we chose to use the SEM for in vivo data because $n=4-6$ and the variability is high. Bars on the graphics are reduce and are more readable. For in vitro data, we chose the SD because $n=3$ and variability between replicates is moderate. Repeated measures ANOVA was performed on dry matter content (DM), local apparent degree of proteolysis (LADP), and molecular weight distributions to detect significant differences; the model included the fixed effects of model, food, time, model*time, model*food, food*time, and food*model*time. A post-hoc LSMEANS test 
was performed when interactions were significant. Differences were considered statistically significant if the p-values were $<0.05$. All statistical analyses were performed using SAS (SAS University Edition, Release 3.71; SAS Institute Inc., Cary, NC, USA). Modelling of marker data was performed with XLSTAT (XLSTAT Quality 18.07, Addinsoft, France). Gastric data were analysed with a principal component analysis (PCA) carried out in XLSTAT.

\section{Results}

\subsection{Effect of the model on dry matter content}

Dry matter content (DM) in the duodenum compartment of the DiDGI ${ }^{\circledast}$ was compared to the DM of samples taken from mini-pigs fitted with a duodenal cannula. Data are presented in Fig. S2. In both the in vivo and in vitro models, DM values globally decreased after the intake of soya milk and tofu (from $13 \%$ to $5 \%$ and from $20 \%$ to $5 \%$, respectively). For both soya milk and tofu, there was a significant model*time interaction: for the digestion of soya milk, DM values were significantly different between in vivo and in vitro models at $270 \mathrm{~min}$, and the same was true for the digestion of tofu at 120 and $180 \mathrm{~min}$. Beside this, no significant differences were detected for DM values throughout the duodenal digestion. Generally speaking, observations made from the different models at a given time point were consistent with each other, with the exception of the instances noted above.

Next, we examined the kinetic evolution of DM values between samples taken from the ileal group of mini-pigs and those taken from the output of the DiDGI ${ }^{\circledast}$ (Fig. 1B). Because of the way the DiDGI ${ }^{\circledast}$ was set up, the tofu chyme arrived in the last compartment more slowly than the soya milk chyme, and the tofu-derived ileal content was collectable only starting from $300 \mathrm{~min}$. A significant model*time interaction was detected for both soya milk $(\mathrm{p}=0.0113)$ and tofu $(\mathrm{p}=0.0329)$. The DM values of in vivo ileal samples were always lower than their corresponding in vitro ileal samples from the DiDGI ${ }^{\circledast}$, but for the soya milk meal, these differences were statistically significant only for the samples taken at $120 \mathrm{~min}(\mathrm{p}=0.0006)$ and $180 \mathrm{~min}$ ( $\mathrm{p}=0.0282$ ). For the tofu meal, instead, in vitro DM was significantly higher than in vivo DM for both sampling times available (300 min and 360 min, $\mathrm{p}<0.0028$ ). This result was expected, as in vivo digestion also includes absorption by the small intestine, which was not simulated during the in vitro dynamic digestion.

\subsection{Effect of the model on local apparent degree of proteolysis}

In the gastric phase (Fig. 2A \& A'), the local apparent degree of proteolysis (LADP) was similar between in vivo and in vitro models for both meals; the only exception to this was found with the tofu meal sampled at $20 \mathrm{~min}$, for which LADP differed in vitro and in vivo ( $p=0.0031$ ). Moreover, the effect of time was not significant, meaning that the kinetics were constant and LADP did not vary significantly as a function of time.

At the duodenal step of the soya milk digestion (Fig. S2B), significantly different LADP values were obtained from the DiDGI ${ }^{\circledast}$ and from mini-pigs only at the end of the assay, at $360 \mathrm{~min}(\mathrm{p}<0.0001)$. For the tofu meal (Fig. S2B), instead, the kinetics of the evolution of LADP were unchanged between in vivo and in vitro models (interaction effect: $\mathrm{p}=0.5954)$. The LADP in the duodenum was determined for each in vitro replicate and animal/food combination between 20 and $180 \mathrm{~min}$ of digestion, and these values were plotted as a function of the dry matter content (DM) of the samples (Fig. 3). There was significantly more variation in duodenal DM (interaction food*time, $\mathrm{p}<0.0001$ ) with the tofu meal (5-23\%) than with the soya milk meal (6-18\%). For this reason, plotted values associated with the tofu meal were highly dispersed on the graphic, with a particularly visible distinction between DiDGI $^{\circledast}$ replicates and the corresponding animal trials. Interestingly, at 20 and $60 \mathrm{~min}$, tofu DM was similar between in vivo and in vitro assays, whereas LADP values obtained from the DiDGI ${ }^{\circledast}$ were lower than those from mini-pigs. At 120 and $180 \mathrm{~min}$, the DiDGI ${ }^{\circledR}$ generated a tofu chyme that was less hydrolysed, and with a lower DM, than that found in mini-pig samples. For digestions of the soya milk meal, the largest differences between in vivo and in vitro tests were found at 20 and 180 min, at which time DM values were lower in the DiDGI ${ }^{\circledast}$ than in the mini-pig duodenum. At the end of digestion, the soya milk meal seemed to be more hydrolysed in the $\operatorname{DiDGI}^{\circledR}(8-11 \%)$ than in vivo $(5-8 \%)$. Overall, the two meals followed two different patterns of digestion in the duodenum (interaction food*time of LADP: $p<0.0001$, and of DM: $\mathrm{p}<0.0001$ ): for soya milk, LADP increased as digestion progressed and the DM decreased, while for tofu, LADP decreased with DM as digestion progressed.

\subsection{Effect of the model on the molecular weight distribution of gastric peptides}

Table S2 presents the results of statistical analyses that examined the relative proportions of gastric peptides, as determined by their molecular weight, in the outputs of the in vivo and in vitro systems at 20 , 60,120 and 180 min after tofu or soya milk meals ingestion. Fig. 4 is a graphical representation of a principal component analysis (PCA) of the proportions of gastric peptides grouped by molecular weight plus the gastric LADP. Only fractions for which at least one significant interaction was detected were included; thus, data for the $>35 \mathrm{kDa}$, 500-800 Da, and 204-500 Da fractions were removed from the PCA. The $\mathrm{x}$-axis, the first principal component, labelled $\mathrm{F} 1$, contributed $46.8 \%$ of the observed variability. It was positively correlated with the proportions of low-molecular-weight fractions $(<2.5 \mathrm{kDa})$ and negatively correlated with the proportions of higher-molecular-weight fractions (>3 kDa) (Fig. 4A). The y-axis, the second principal component, labelled F2, contributed $21.5 \%$ of the observed variability and was positively correlated with the proportion of the $2.5-3 \mathrm{kDa}$ fraction (Fig. 4A). In Fig. 4B to 4E, each sample is plotted on this plane in order to observe the evolution of the in vivo or in vitro digestions between 20 and $180 \mathrm{~min}$. The first observation to note is that the variability among animals was higher than the variability between in vitro assays. Indeed, for each food and at each time, the DiDGI ${ }^{\circledR}$ replicates (of tofu and soya milk digestions in Fig. 4B and Fig. 4C respectively) group together, whereas the replicates of digestion in each pig were quite distinct (Fig. 4D and 4E). At $20 \mathrm{~min}$ of digestion, in vivo and in vivo data were on different side of the factorial plan: gastric peptides observed in vivo were larger $(>3 \mathrm{kDa})$ than those observed in vitro $(<2.5 \mathrm{kDa})$. Then, the distribution of gastric peptides tended to become similar along the digestion. As gastric digestion progressed, the proportion of $2-3 \mathrm{kDa}$ peptides increased globally, so that most assays reached the same area on the factorial plane at $180 \mathrm{~min}$. Exceptions were observed in two animals who ingested the soya milk meal. A high degree of divergence was observed at $20 \mathrm{~min}$ for in vivo data, but starting from $120 \mathrm{~min}$, proteolysis patterns from most animals were similar to each other. No clear difference between meals was observed in vivo whereas in the in vitro digestion of the tofu and the soya milk meals, the relative proportion of the $2-3 \mathrm{kDa}$ fraction appeared to increase more slowly for the soya milk meal than for the tofu meal.

In particular, proportions of three fractions-1.5-2 $\mathrm{kDa}$ $(\mathrm{p}=0.0070), 1-1.5 \mathrm{kDa}(\mathrm{p}=0.0003)$, and $0.8-1 \mathrm{kDa}$ ( $\mathrm{p}<0.0001$ )—evolved differently over time in the two models (Fig. S4 C, D, and E). In each case, the DiDGI ${ }^{\circledR}$ yielded decreasing or morestable values than mini-pigs. In analysing the fractions, we also noted the following interesting results:

- In the 10-18 kDa fraction (Fig. S4 A), there were significant effects of the interactions model*food ( $\mathrm{p}=0.0347)$ and model*food*time $(p=0.0499)$, but not of the interactions food*time $(p=0.4915)$ and model*time $(\mathrm{p}=0.1323)$. Indeed, the proportion of this fraction increased over time in the DiDGI ${ }^{\circledast}$ but remained constant in the 

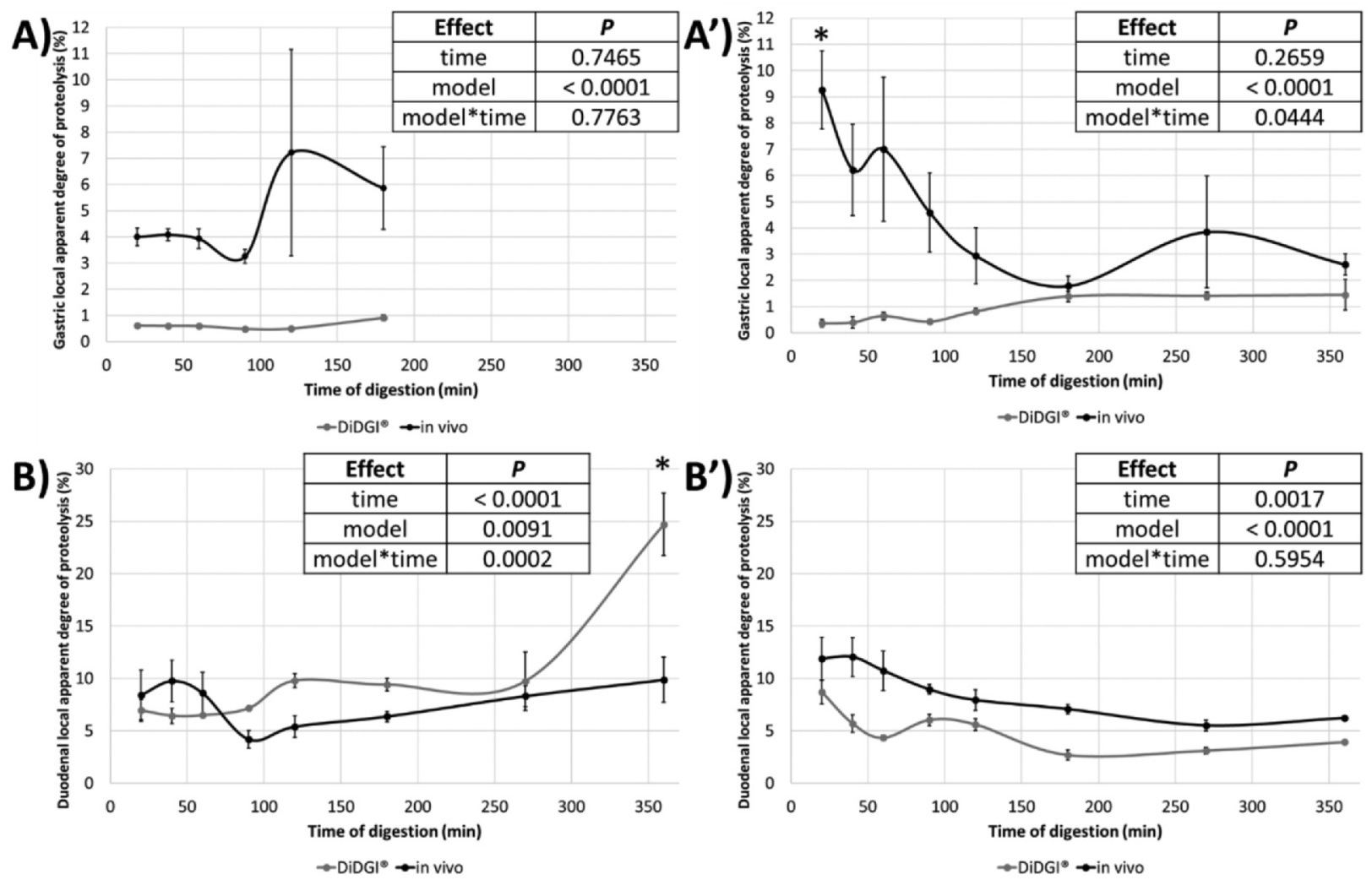

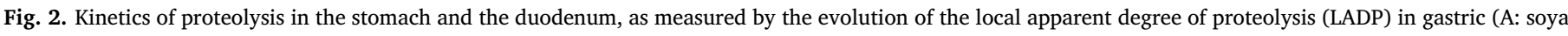

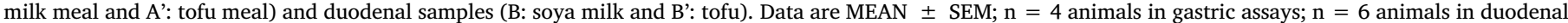

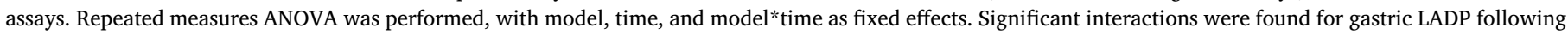

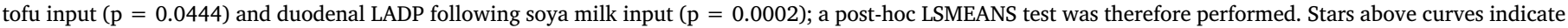
a significant difference between models at the given sampling time $(\mathrm{p}<0.05)$.

mini-pig model.

- In the 2.5-3 kDa fraction (Fig. S4 B), there were significant effects of the interactions model*time ( $\mathrm{p}=0.0232)$ and model*food*time $(\mathrm{p}=0.0439)$, but not the interactions food*time $(\mathrm{p}=0.1674)$ and model*food ( $\mathrm{p}=0.9487$ ). Proportions of the 2.5-3 kDa fraction evolved differently between models, and the effect of the model differed between the tofu meal and the soya milk meal.

- In the 1-1.5 kDa fraction (Fig. S4 D), we detected the significant interactions model*time $(\mathrm{p}=0.0003)$ and food*time $(\mathrm{p}=0.0015)$, but the third-order interaction, model*food*time, was not significant ( $\mathrm{p}=0.5582)$. A compensation phenomenon occurred, in which different kinetics were observed between the tofu and the

\section{A) Soya milk}

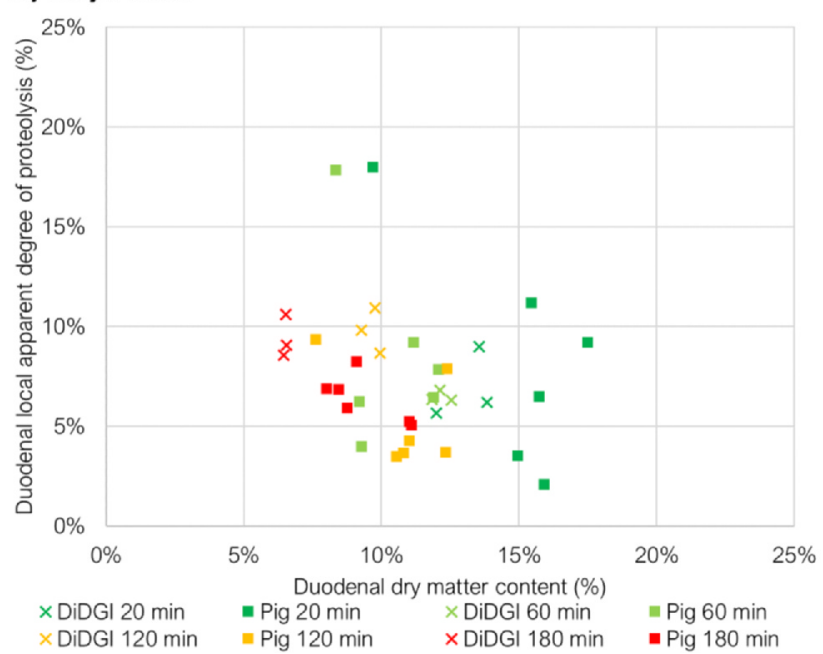

B) Tofu

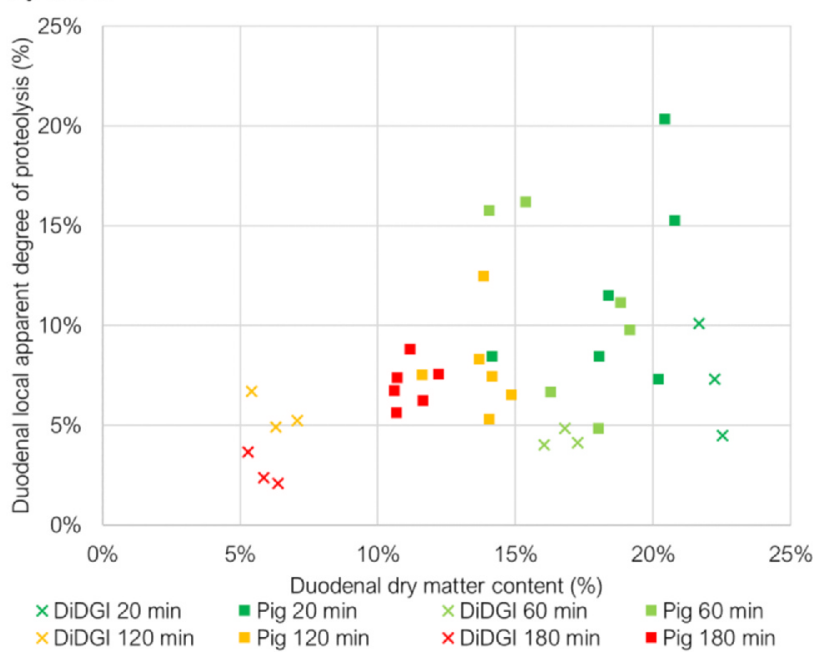

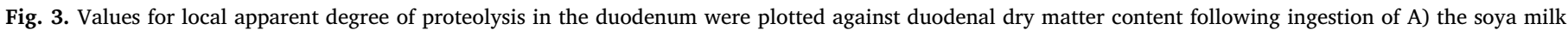

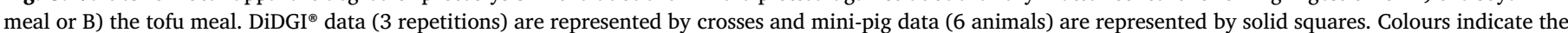

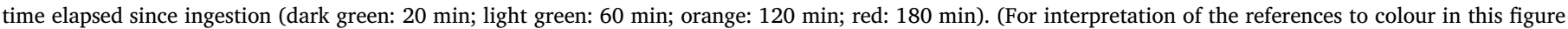
legend, the reader is referred to the web version of this article.) 


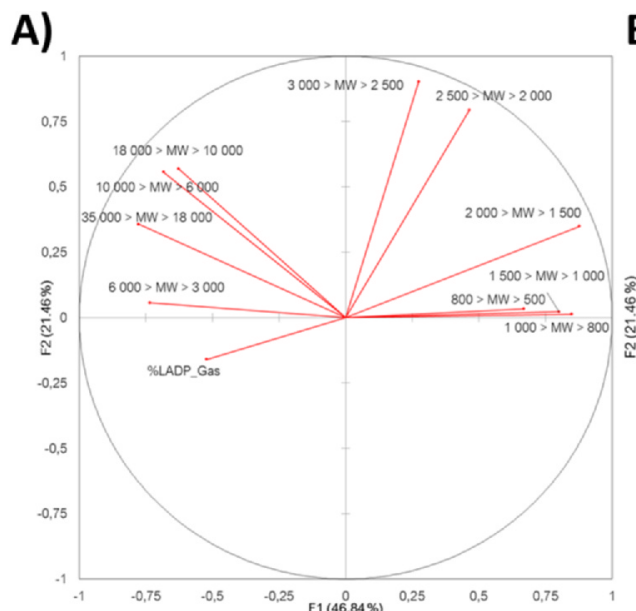

B)

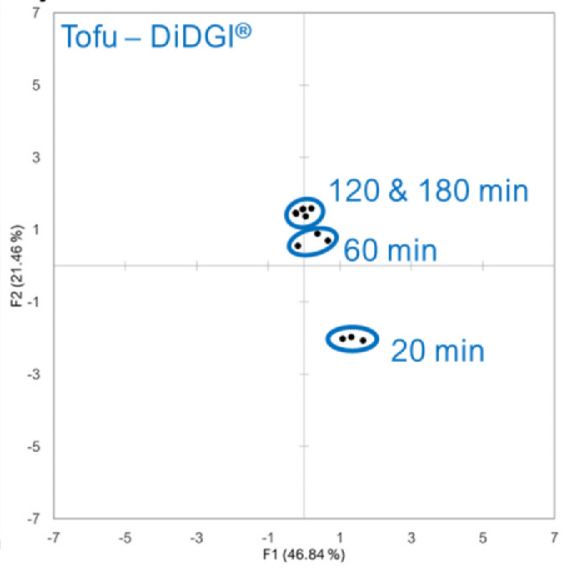

C)

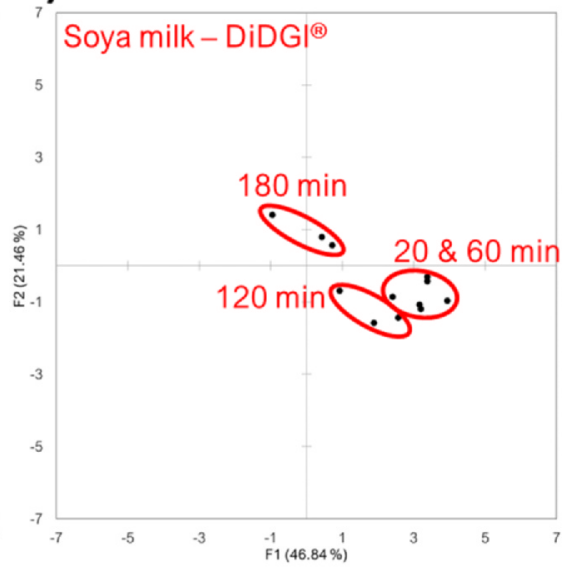

D) Tofu - in vivo
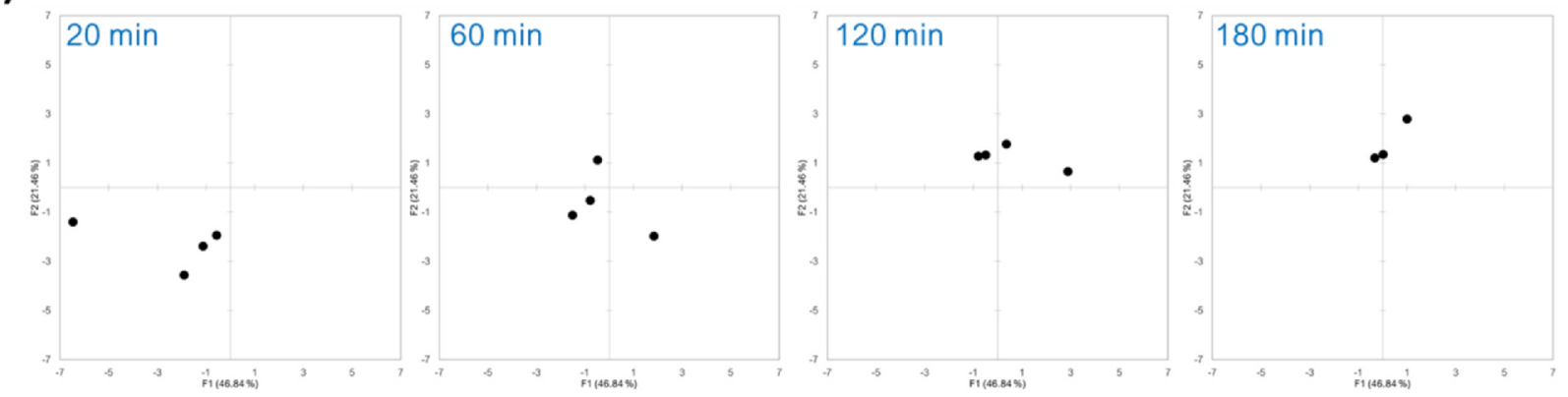

E) Soya milk - in vivo
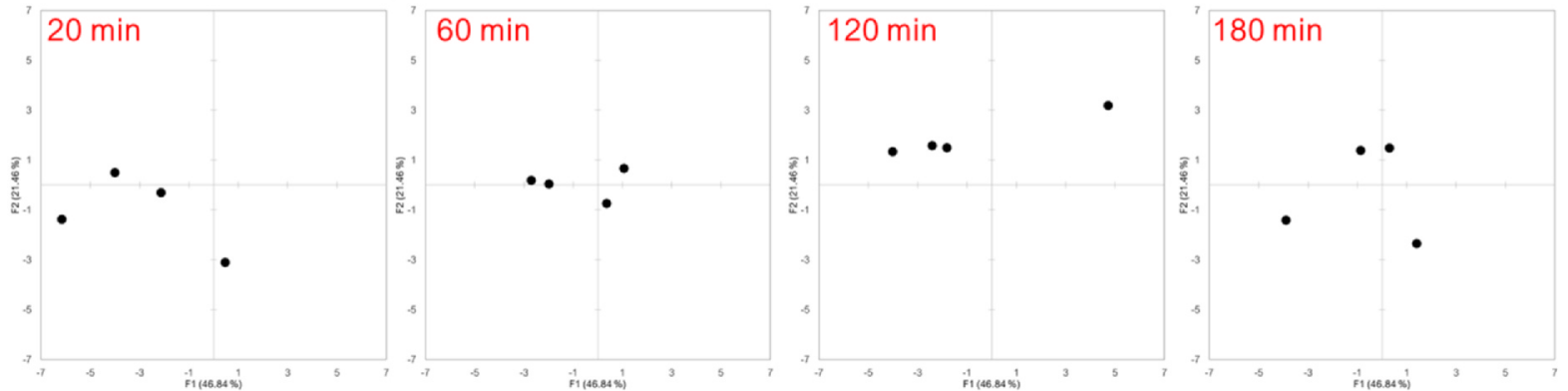

Fig. 4. Results from animal/in vitro trials visualised using a Principal Components Analysis (PCA) of the molecular weight distributions of peptide fractions and the local apparent degree of proteolysis in the stomach. A) Graphical representation depicting the circle of correlation and contribution of each variable to the $x$ - and yaxes. B) Graphical representation of the tofu meal digestion at different times in the first compartment of the DiDGI ${ }^{\odot}$. C) Graphical representation of the soya milk meal digestion at different times in the first compartment of the DiDGI ${ }^{\circledast}$. D) Graphical representations of the tofu meal digestion at different times in the stomach of mini-pigs E) Graphical representations of the soya milk meal digestion at different times in the stomach of mini-pigs. $\mathrm{n}=4$ animals (except for the tofu in vivo at 180 min where $\mathrm{n}=3$ ) and $\mathrm{n}=3$ in vitro assays.

soya milk meals in the DiDGI ${ }^{\circledR}$, but not in mini-pigs. Furthermore, until $120 \mathrm{~min}$, higher proportions of this fraction were detected in the soya milk meal in mini-pigs than in the DiDGI ${ }^{\circledast}$ or from the tofu meal in either model.

\subsection{Effect of the model on ileal digestibility}

Table 2 shows the in vivo and in vitro digestibility of the tofu and soya milk meals. For the in vitro calculations, the difference between endogenous and dietary nitrogen was not considered. Moreover, because no significant difference was observed between the two meals with respect to the true ileal digestibility in vivo (soya milk meal: $99.4 \pm 2.4 \%$; tofu meal:101.8 $\pm 8.9 \%$ ), only the in vivo apparent ileal digestibility was compared with the in vitro digestibility of nitrogen. Although a significant effect was detected for food $(p=0.0365)$, there was no effect of model ( $p=0.4207$ ) or of the model*food interaction $(\mathrm{p}=0.5805)$.
Table 2

Comparison of crude protein $(\mathrm{N} \times 6.25)$ digestibility values obtained in vivo and in vitro for meals based on tofu and on soya milk. Values indicate percentage of crude protein (\%) (MEAN \pm SEM). A two-way ANOVA was performed on the in vitro and in vivo apparent digestibilities. p-values of effects were: model: $\mathrm{p}=0.4207$; food: $\mathrm{p}=0.0365$; model ${ }^{*}$ food: $\mathrm{p}=0.5805$. Different letters $(\mathrm{a}$ and $\mathrm{b})$ indicate significant differences $(\mathrm{p}<0.05)$.

\begin{tabular}{llll}
\hline Model & Type of digestibility & Soya Milk & Tofu \\
\hline \multirow{2}{*}{ in vivo } & True & $99.4 \pm 2.2 \%$ & $97.0 \pm 3.9 \%$ \\
& Apparent & $71.3 \pm 2.5 \%^{\mathrm{a}}$ & $56.5 \pm 6.4 \%{ }^{\mathrm{b}}$ \\
in vitro & Centrifugation & $72.7 \pm 1.4 \%^{\mathrm{a}}$ & $63.7 \pm 3.5 \%^{\mathrm{b}}$ \\
\hline
\end{tabular}

Indeed, when we performed a simple centrifugation of ileum content from the DiDGI ${ }^{\circledR}$, and considered the supernatant as absorbed and the pellet as undigested, we obtained the same range of values for nitrogen digestibility as those obtained in vivo. 
The difference in the apparent ileal digestibility of nitrogen measured in vivo between the soya milk meal $(71.3 \pm 2.5 \%)$ and the tofu meal $(56.5 \pm 7.8 \%)$ was also found using the DiDGI ${ }^{\circledR}$ system, with the in vitro digestibility of nitrogen from soya milk and tofu equal to $72.7 \pm 1.4 \%$ and $63.7 \pm 3.5 \%$, respectively.

As the soya milk and the tofu meals were totally digestible when we examined the in vivo true ileal digestibility, we expect that the nitrogen measured in the pellet of in vitro ileal content likely came from endogenous secretions.

\section{Discussion}

Other studies have compared in vivo data from pig experiments with the nitrogen balance resulting from in vitro digestions that included a filtration/dialysis step to simulate intestinal absorption (Babinszky et al., 1990; Boisen and Fernández, 1995; Minekus, 1998; Cho and Kim, 2011). There have also been investigations focused on individual amino acids, which have yielded contrasting results depending on the amino acid under consideration (Boisen and Fernández, 1995; Pujol and Torrallardona, 2007; Jezierny et al., 2010; Cho and Kim, 2011). In the literature, most of the recent examinations of the correlation between in vivo and in vitro protein digestion have used milk proteins, which are almost completely digested at the ileum stage (Minekus, 1998). For this reason, efforts have been made to compare the evolution of proteolysis throughout digestion and not only the end results (Egger et al., 2015). Here, we aimed to build on these previous works by investigating the condition of proteins throughout the digestive process.

In the ileum, proportions of in vivo digestible nitrogen and in vitro simulated-absorbed nitrogen were similar, and the difference between the soya milk and tofu meals was conserved from one model to another. Early studies correlating measures of $\mathrm{pH}$ drop in vitro with the apparent or true fecal digestibility of protein in vivo were performed on a large spectrum of foodstuffs, including plant-based foods (Hsu et al., 1977; Perdersen and Eggum, 1981), but these results were shown to be highly dependent on the individual buffering capacity of a food created by its mineral and protein content (Moughan et al., 1989). Later, Ihekoronye (1986) compared the final degree of hydrolysis in vitro, measured with TNBS, with measures of apparent fecal digestibility obtained from rats (Satterlee, Kendrick and Miller, 1977) and in doing so found similar values for textured soya protein (in vivo: $83.3 \%$, in vitro: $83.7 \%$ ) and solubilised soya flour (in vivo: $78.9 \%$, in vitro: $80.0 \%$ ). Here, instead, the apparent digestibility of our two soya-based food products was markedly lower than those previously published values: 10 points lower for soya milk, 20 points lower for tofu. Such a difference could originate from numerous factors, such as differences between the models used or in the food items studied.

In the duodenum, differences in DM kinetics might have arisen from different sources, such as inappropriate patterns of gastric emptying and/or dilution of the chyme in endogenous secretions (basal and postprandial, gastric and duodenal). In vivo, we expected a higher amount of endogenous secretion because of the contributions of mucus and hormone secretions, as well as cell desquamation, that were not considered in in vitro assays. The differences observed in LADP may have been due in part to variations in the quantity of digestive enzymes secreted (pepsin and pancreatin) and the dynamic of bolus transfer from one compartment to another. The most important factor, though, may have been changes in the local ratio of protease to protein. We had expected that the concentration of endogenous nitrogen compounds would be higher in the mini-pig duodenum than in the second compartment of the DiDGI ${ }^{\oplus}$; however, no significant difference was observed between models with respect to the total nitrogen content of gastric samples (0.1-0.7 gN.100 $\mathrm{g}^{-1}$ ) or duodenal samples (0.1-0.4 gN.100 $\mathrm{g}^{-1}$ ). Moreover, in mini-pig experiments, the position of the duodenal cannula was set between the pylorus and the common bile/ pancreatic ducts. This meant that, in in vivo duodenal samples, pancreatic enzymes were perhaps not even present at their maximal levels.
Some studies have investigated correlations of protein digestion between an in vivo model and a dynamic in vitro system by comparing transfers and $\mathrm{pH}$ modification through the digestive process (Dupont et al., 2019). Minekus (1998) examined the delivery and the absorption of dietary nitrogen in the different compartments of the system and compared this with marker data obtained from cannulated animals. In that study, though, protein hydrolysis was investigated only indirectly, by analysing the absorption of nitrogen (Minekus, 1998). Instead, Chiang and colleagues (2008) investigated the gastric digestibility of protein by TCA precipitation in vivo and in a dynamic in vitro system, and found a strong correlation between the two models $(r=0.97$; $\mathrm{p}=0.0001$ ). TCA precipitation is a good first step to evaluate the state of proteins in a mixture, but here we went further by looking at the degree of hydrolysis of proteins and at the distribution of peptides by their molecular weights.

In the stomach, we were unable to precisely track the evolution of the local apparent degree of proteolysis of the tofu meal due to the high inter-individual variability in animals, the low number of mini-pigs involved, and the nature of the sampling scheme. Thus, the main comparisons that we were able to make between the tofu and soya milk meals with respect to gastric digestion were based on the molecular weight distributions of peptides. Here, the interaction food*time had a significant effect on the proportions of the $1-1.5 \mathrm{kDa}$ and free amino acid fractions $(<204 \mathrm{kDa}$ ). Moreover, the $0.8-1 \mathrm{kDa}$ and 204-500 Da fractions; in vivo, were more abundant in the soya milk meal than in the tofu meal. As final point of discussion, the tofu left the stomach more rapidly than the soya milk. It is because of the difference regarding the gastric emptying equations. However, after soya milk intake, gastric content was collectable from the DiDGI ${ }^{\circledast}$ for only $180 \mathrm{~min}$, while in vivo, this content was collectable for $450 \mathrm{~min}$. According to the recovered markers, at 180 min most of the soya milk chyme had emptied from the pig stomach, and content sampled after that time originated mostly from endogenous secretions.

\section{Conclusion}

In the present study, we elaborated a food-dependent digestion programme for the DiDGI ${ }^{\circledast}$ based on experimental data obtained from mini-pigs. We used this to then investigate the correlation between these two models with respect to the dry matter content in the duodenum and the ileum, the local apparent degree of proteolysis in the stomach and in the duodenum, and the molecular weight distribution of gastric peptides. Globally, no clear correlation was found at the gastric step because of the inter-individual variability of pigs and an inadequate release of pepsin in the DiDGI ${ }^{\circledR}$. However, at a later stage of digestion, when the stomach was almost emptied, proteolysis patterns were largely consistent between models, especially for the tofu digestion. Differences were found in individual parameters in the duodenal phase, but the global kinetics were consistent from one model to another. Finally, from the ileal phase, we obtained similar values for nitrogen digestibility in both in vivo and in vitro models.

\section{Declaration of Competing Interest}

The authors declare that they have no known competing financial interests or personal relationships that could have appeared to influence the work reported in this paper.

\section{Acknowledgements}

We thank our animal housing manager, Julien Hermet, and our animal housing workers, Philippe Lhoste and Yohan Delorme. We are grateful to Caroline Buffière, Benoît Cohade, Mélissa Vauris and Kevin Liebermann who participate to in vivo experiments, to Hervé Guillemin and Thomas Cattenoz for helping to develop food-dependent set-up of 
the DiDGI ${ }^{\circledR}$ dynamic in vitro system, and to Lindsay Higgins for correcting the English of the manuscript. Finally, we would like to acknowledge the contribution of Denys Durand, who performed surgery with Didier Rémond.

\section{Author Contributions}

Conceptualization: YR, DD, DR, IS, DP and ML, Data curation: YR, Formal analysis: YR, Funding acquisition: DD, DR, IS, DP and ML, Investigation: YR, AC, DF, and AM, Methodology: DD, IS, DP, ML, AC and YR, Supervision: DD, DR, IS, DP and ML, Visualization: YR, Writing - original draft: YR, Writing - review \& editing: All authors.

\section{Funding}

The project was funded by IMPROVE SAS and INRAE. A PhD grant was funded by IMPROVE SAS through a CIFRE procedure (CIFRE $\mathrm{n}^{\circ} 2016 / 0719$ )

\section{Appendix A. Supplementary data}

Supplementary data to this article can be found online at https:// doi.org/10.1016/j.foodchem.2020.128276.

\section{References}

Adouard, N., et al. (2016). Survival of cheese-ripening microorganisms in a dynamic simulator of the gastrointestinal tract. Food Microbiology, 53, 30-40. https://doi.org/ 10.1016/j.fm.2015.03.002.

Babinszky, L., et al. (1990). An In-Vitro Method for Prediction of the Digestible Crude Protein Content in Pig Feeds. Journal of the Science of Food and Agriculture, 50, 173-178.

Bauchart, C., et al. (2007). Peptides reproducibly released by in vivo digestion of beef meat and trout flesh in pigs. British Journal of Nutrition, 98(6), 1187-1195. https:// doi.org/10.1017/S0007114507761810.

Binnerts, W. T., Van't Klooster, A. T., \& Frens, A. M. (1968). Soluble chromium indicator measured by atomic absorption in digestion experiments. Veterinary Record, 82.

Bohn, T., et al. (2018). Correlation between in vitro and in vivo data on food digestion. What can we predict with static in vitro digestion models? Critical Reviews in Food Science and Nutrition, 58(13), 2239-2261. https://doi.org/10.1080/10408398.2017. 1315362.

Boisen, S., \& Fernández, J. A. (1995). Prediction of the apparent ileal digestibility of protein and amino acids in feedstuffs and feed mixtures for pigs by in vitro analyses. Animal Feed Science and Technology, 51(1-2), 29-43. https://doi.org/10.1016/03778401(94)00686-4.

Brodkorb, A., et al. (2019). INFOGEST static in vitro simulation of gastrointestinal food digestion. Nature Protocol, 14(4), 991. https://doi.org/10.1038/s41596-018-0119-1.

Cho, J. H., \& Kim, I. H. (2011). Evaluation of the Apparent Ileal Digestibility (AID) of Protein and Amino Acids in Nursery Diets by In vitro and In vivo Methods. Asian-Aust. J. Anim. Sci. 24(7), 1007-1010. https://doi.org/10.5713/ajas.2011.10435.

Davies, B., \& Morris, T. (1993). Physiological Parameters in Laboratory Animals and Humans. Pharmaceutical Research, 10(7), 1093-1095.

Dupont, D., et al. (2019). 'Can dynamic in vitro digestion systems mimic the physiological reality?', Critical Reviews in Food Science and Nutrition. Taylor \& Francis, 59(10), 1546-1562. https://doi.org/10.1080/10408398.2017.1421900.

Egger, L., et al. (2015). 'The harmonized INFOGEST in vitro digestion method: From knowledge to action. Food Research International The Authors, 88, 217-225. https:// doi.org/10.1016/j.foodres.2015.12.006.

Elashoff, J., Reedy, T., \& Meyer, J. (1982). Analysis of gastric emptying data, Gastroenterology. American Gastroenterological Association, 83(6), 1306-1312. https://doi.org/10.1016/S0016-5085(82)80145-5.

European Commission (2009) Commission Regulation (EC) No 152/2009 of 27 January 2009 laying down the methods of sampling and analysis for the official control of feed. Annexe III.

FAO (2013) Report of an FAO Expert Consultation: Dietary protein quality evaluation in human nutrition.

Guerra, A., et al. (2016). Development and Validation of a New Dynamic ComputerControlled Model of the Human Stomach and Small Intestine. Biotechnology and Bioengineering, 113(6), 1325-1335. https://doi.org/10.1002/bit.25890.

Henze, L. J., et al. (2018). The pig as a preclinical model for predicting oral bioavailability and in vivo performance of pharmaceutical oral dosage forms : A PEARRL review. Journal of Pharmacy and Pharmacology, 71, 581-602. https://doi.org/10.1111/jphp. 12912

Hsu, H. W., et al. (1977). A Multienzyme Technique for Estimating Protein Digestibility.
Journal of Food Science, 42(5), 1269-1273. https://doi.org/10.1111/j.1365-2621. 1977.tb14476.x.

Ihekoronye, A. I. (1986). Rapid in vitro enzymic predictive model for the in vivo digestibility of food proteins. Journal of Food Technology, 21, 81-87.

ISO Céréales, produits céréaliers et aliments des animaux - Détermination de la teneur en matières grasses brutes et en matières grasses totales par la méthode d'extraction de Randall Méthode NF ISO 11085. www.iso.org 2008 Geneva, Switzerland.

Jezierny, D., et al. (2010). In vitro prediction of standardised ileal crude protein and amino acid digestibilities in grain legumes for growing pigs. Animal, 4(12), 1987-1996. https://doi.org/10.1017/S1751731110001114.

Mainville, I., Arcand, Y., \& Farnworth, E. R. (2005). A dynamic model that simulates the human upper gastrointestinal tract for the study of probiotics. International Journal of Food Microbiology, 99(3), 287-296. https://doi.org/10.1016/j.ijfoodmicro.2004.08. 020 .

Mariotti, F., Tomé, D., \& Mirand, P. P. (2008). Converting nitrogen into protein - Beyond 6.25 and Jones' factors. Critical Reviews in Food Science and Nutrition, 48(2), 177-184. https://doi.org/10.1080/10408390701279749.

Ménard, O., et al. (2014). Validation of a new in vitro dynamic system to simulate infant digestion. Food Chemistry, 145, 1039-1045. https://doi.org/10.1016/j.foodchem. 2013.09.036.

Minekus, M. (1998) Development and Validation of a Dynamic Model of the Gastrointestinal Tract. PhD Thesis, Utrecht University. Elinkwijkb.v.: Utrecht, Netherlands. (ISBN: 90-393-1666-x).

Minekus, M., et al. (2014). A standardised static in vitro digestion method suitable for food - an international consensus. Food \& Function, 5(6), 1113-1124. https://doi.org/ 10.1039/c3fo60702j.

Minekus, M. (2015). The TNO Gastro-Intestinal Model (TIM). In K. Verhoeckx (Ed.). The Impact of Food Bioactives on Health: in vitro and ex vivo models (pp. 37-46). Cham: Springer International Publishing. https://doi.org/10.1007/978-3-319-16104-4_5.

Moore, S., \& Stein, W. H. (1954). A modified ninhydrin reagent for the photometric determination of amino acids and related compounds. Journal of Biological Chemistry, 211(2), 907-913.

Moughan, P. J., et al. (1989). In-vitro Determination of Nitrogen Digestibility and Lysine Availability in Meat and Bone Meals and Comparison with in-vivo Ileal Digestibility Estimates. Journal of the Science of Food and Agriculture, 47(3), 281-292.

Nunez, P., Bichot, C. H. U. X., \& Paris, H. (1998). Interests of the "artifical stomach" techniques to study antacid formulations: Comparison with in vivo evaluation. Fundamental and Clinical Pharmacology, 12, 573-583.

Perdersen, B., \& Eggum, O. (1981). Prediction of protein digestibility by in vitro procedures based on two mullti-enzyme systems. Zeitschrift für Tierphysiologie Tierernährung und Futtermittelkunde, 45(1-5), 190-200.

Pujol, S., \& Torrallardona, D. (2007). Evaluation of in vitro methods to estimate the in vivo nutrient digestibility of barley in pigs. Livestock Science, 109(1-3), 186-188. https://doi.org/10.1016/j.livsci.2007.01.143.

Reynaud, Y., Buffière, C., Cohade, B., Vauris, M., Liebermann, K., Hafnaoui, N., .. Rémond, D. (2021). True ileal amino acid digestibility and digestible indispensable amino acid scores (DIAASs) of plant-based protein foods. Food Chemistry, 338, Article 128020. https://doi.org/10.1016/j.foodchem.2020.128020 ISSN 0308-8146.

Reynaud, Y., Buffière, C., David, J., Cohade, B., Vauris, M., Lopez, M., ... Rémond, D. (2020). Temporal changes in postprandial intragastric $\mathrm{pH}$ : Comparing measurement methods, food structure effects, and kinetic modelling. Food Research International. Elsevier Ltd. https://doi.org/10.1016/j.foodres.2019.108784.

Reynaud, Y., Lopez, M., Riaublanc, A., Souchon, I., \& Dupont, D. (2020). Hydrolysis of plant proteins at the molecular and supra-molecular scales during in vitro digestion. Food Research International. Elsevier, 134(September 2019), Article 109204. https:// doi.org/10.1016/j.foodres.2020.109204.

Rozan, P., et al. (1997). In Vivo and in Vitro Digestibility of Soybean, Lupine, and Rapeseed Meal Proteins after Various Technological Processes. Journal of Agricultural and Food Chemistry, 45(5), 1762-1769. https://doi.org/10.1021/jf960723v.

Satterlee, L. D., Kendrick, J. G., \& Miller, G. A. (1977). Rapid in vitro assays for estimating protein quality [of food]. Nutrition Reports International.

Saunders, R. M., Connor, M. A., \& Booth, A. N. (1973). Measurement of Digestibility of Alfalfa Protein Concentrates by in vivo and in vitro Methods. The Journal of nutrition, 103(4), 530-535.

Siddons, R. C., et al. (1985). Ytterbium acetate as a particulate-phase digesta-flow marker. The British journal of nutrition, 54(2), 509-519. https://doi.org/10.1079/ BJN19850136.

Tavano, O. L., Neves, V. A., \& da Silva Júnior, S. I. (2016). 'In vitro versus in vivo protein digestibility techniques for calculating PDCAAS (protein digestibility-corrected amino acid score) applied to chickpea fractions', Food Research International. Elsevier Ltd, 89, 756-763. https://doi.org/10.1016/j.foodres.2016.10.005.

Thiex, N. J., Manson, H., Anderson, S., \& Persson, J.Å. (2002). Determination of crude protein in animal feed, forage, grain, and oilseeds by using block digestion with a copper catalyst and steam distillation into boric acid: Collaborative study. Journal of AOAC International, 85(2), 309-317.

Vachon, C., et al. (1987). Relationship between in vitro digestion of proteins and in vivo assessment of their nutritional quality. Reproduction and Nutrition Dévelopment, 27(3), 659-672.

Walther, B., et al. (2019). GutSelf: Inter-Individual Variability in the Processing of Dietary Compounds by the Human Gastrointestinal Tract. Molecular Nutrition \& Food Research. https://doi.org/10.1002/mnfr.201900677. 